\title{
Expression of parathyroid hormone-related protein mRNA by uterine tissues and extraembryonic membranes during gestation in rats
}

\author{
F. Beck, J. Tucci and P. V. Senior \\ Howard Florey Institute of Experimental Physiology and Medicine. University of Melbourne, \\ Parkville, Victoria, Australia 3052
}

\begin{abstract}
Hybridization histochemistry and solution hybridization studies were performed to localize the expression of parathyroid hormone-related protein $(\mathrm{PTHrP})$ during implantation in rats. Parallel studies were performed on rat uteri bearing oil-induced deciduomata and on cultured blastocysts. PTHrP mRNA begins to be expressed at day 5.5 of gestation by the uterine epithelium in the anti-mesometrial crypts marking the sites of implantation and in comparable regions during induction of deciduoma. Trophoblastic giant cells express the gene as soon as they are phenotypically recognizable both in vivo and in culture, but PTHrP mRNA cannot be detected in the early blastocyst or in cells of the inner cell mass. Decidual cells produce PTHrP mRNA both in normal gestation and after the induction of deciduomata. In each case, the expression of the gene in decidual cells follows its expression in uterine epithelium by $48 \mathrm{~h}$. The uterine topographical location and time of expression of the PTHrP gene suggests that it plays a part in the implantation of the blastocyst.
\end{abstract}

\section{Introduction}

The major humoral factor causing hypercalcaemia of malignancy (Martin, 1988) is parathyroid hormone-related protein (PTHrP). This hormone is secreted by a variety of squamous cell carcinomata, and by a number of other epithelial tumour cells and by T cells in HTKV-I type leukaemia. Purified preparations of PTHrP were originally obtained from a human cẹll line (BEN) derived from a squamous cell carcinoma of the lung (Moseley $e t$ al., 1987) and from a breast carcinoma (Burtis et al., 1987). Partial amino acid sequencing then allowed the preparation of oligonucleotide probes and the characterization of cDNA clones from a BEN library (Suva et al., 1987). Subsequently, the organization of the human, rat, mouse and chicken PTHrP genes were elucidated and upstream control motifs for cAMP, 1,25-dihydroxy vitamin $D_{3}$ and glucocorticoids defined (Martin et al., 1991). Under certain conditions, transcriptional upregulation by oestrogens (Thiede et al., 1991), epidermal growth factor (Ernst et al., 1989), transforming growth factor $\beta$ (Kiriyama et al., 1991) and prolactin (Thiede, 1989) in addition to downregulation by dexamethasone (Lu et al., 1989) and vitamin D (Burtis et al., 1987) have been described.

The occurrence of gene transcription (Thiede, 1989; Senior et al., 1991) and translation (Thiede and Rodan, 1988; Moniz et al., 1990) in normal tissues of developing and adult animals is well established. Immunocytochemical investigations indicate widespread fetal distribution of the protein involving not only epithelial tissues but also striated, smooth and cardiac muscle, as well as testis, ovary and brain (Moniz et al., 1990; Campos et al., 1991; Moseley et al., 1991). Northern blot analysis (Ikeda ef al., 1988; Moniz et al., 1990) and polymerase chain reaction

Received 5 October 1992.
(PCR) studies (Selvanayagan et al., 1991) confirm widespread expression of the gene but, using hybridization histochemistry (Senior et al., 1991), which is more limited in sensitivity, large amounts of PTHrP mRNA can be seen only in restricted regions of the fetus, notably in epithelial anlagen of skin appendages, teeth and bronchi.

During early rat gestation, both immunocytochemical (Campos et al., 1991) and molecular (Senior et al., 1991) observations indicate that PTHrP is produced by the pregnant uterus. Trophoblastic giant cells are involved (Senior et al., 1991) but embryonic and fetal tissues do not appear to produce PTHrP or its mRNA in amounts that can be detected by immunocytochemistry or hybridization histochemistry until after at least day 12 of gestation (Campos et al., 1991; Senior et al., 1991). The extent to which maternal uterine tissues transcribe the gene has not been fully defined; Thiede et al. (1990) demonstrated that PTHrP mRNA and protein in pregnant rat myometrium rise dramatically in the $48 \mathrm{~h}$ immediately preceding parturition in regions of uterine occupancy. Further experiments (Thiede et al., 1991) showed that oestrogen regulates amounts of myometrial PTHrP mRNA.

In the experiments described here PTHrP mRNA begins to be expressed at day 5.5 by the uterine epithelium in antimesometrial regions which accurately pick out the sites of blastocyst implantation. It is also demonstrable in uterine epithelium at comparable times during deciduoma induction. In addition, decidual cells produce abundant PTHrP mRNA at both normal gestation and following the production of deciduomata. The early blastocyst does not express detectable PTHrP mRNA, but trophoblastic giant cells express the gene as soon as they are phenotypically differentiated both in vivo and in culture. Thus, the presence of a blastocyst is not required as a specific stimulus for uterine PTHrP gene expression and 
conversely a uterine milieu is not necessary for the output of PTHrP mRNA by differentiating trophoblastic giant cells.

\section{Materials and Methods}

\section{Animals}

Virgin female Sprague-Dawley rats between 6 and 9 months of age and males between 6 and 18 months of age were housed in natural daylight. Males were kept in separate cages and females were caged in groups of three or four. Food and water was available ad libitum. Pregnancy was timed from midnight preceding the morning on which a vaginal plug was detected when single males and females were caged together overnight. Uteri were collected near midday from day 4.5 of gestation onwards from animals that had been given a fatal injection of Lethobarb (Arnolds, Reading). At day $5.5,0.5 \mathrm{ml}$ of a saturated solution of Evans blue (ICN Biomedicals, Sydney) was injected into the aorta of deeply anaesthetized animals about $10 \mathrm{~min}$ before fixation of the uterus which then exhibited blue spots at sites of implantation. At later stages of pregnancy these sites were identified by the presence of uterine swellings.

\section{Probes}

The method of RNA probe transcription for hybridization histochemistry was identical to that described by Senior $e t$ al. (1991) using a $330 \mathrm{bp} \mathrm{cDNA}$ for rat PTHrP coding for amino acids 34 to beyond the end of the coding region as a template. Anti-sense and control sense probes were transcribed, using ${ }^{35}$ SJUTP (1500 Ci mmol ${ }^{-1}$, DuPont Australia Ltd) as label. Yield and quality of transcript were assessed by DE-81 paper chromatography and $4 \%$ polyacrylamide gel electrophoresis, respectively. Probes were subjected to alkaline hydrolysis, precipitated in ethanol, and stored in $10 \mathrm{mmol}$ dithiothreitol $\mathrm{l}^{-1}$ at $-70^{\circ} \mathrm{C}$ until use.

For RNAse protection studies, anti-sense probes for PTHrP and $\beta$-actin were transcribed in an identical manner but $100 \mu \mathrm{Ci}$ of $\left[{ }^{32} \mathrm{P}\right]$ UTP $\left(3000 \mathrm{Ci} \mathrm{mmol}^{-1}\right.$; Bresatec, Australia) was used. After transcription, the probes were extracted twice with phenol (pH 6.0):chloroform:isoamyl alcohol $(25: 24: 1 \mathrm{v} / \mathrm{v})$ and ethanol precipitated in the presence of $10 \mu \mathrm{g}$ Escherichia coli tRNA. After centrifugation ( $11600 \mathrm{~g}$ for $15 \mathrm{~min}$ ), the probes were resuspended in $20 \mu \mathrm{l} 10 \mathrm{mmol} \mathrm{NaCl}^{-1}, 40 \mathrm{mmol}$ Tris- $\mathrm{HCl} \mathrm{I}^{-1}$ ( $\mathrm{pH} 7.5$ ), $6 \mathrm{mmol}^{-1} \mathrm{MgCl}_{2} \mathrm{I}^{-1}, 2 \mathrm{mmol}$ spermidine $\mathrm{1}^{-1}, 2 \mathrm{U}$ RNAse-free DNase I (Promega, Australia) 40U RNAsin (Promega, Australia) and incubated at $37^{\circ} \mathrm{C}$ for $1.5 \mathrm{~h}$. The probes were loaded on to a $6 \%$ polyacrylamide gel. After electrophoresis, the gel was wrapped in Gladwrap and autoradiographed for $2 \mathrm{~min}$. The band corresponding to the full length probe was cut from the gel using the autoradiograph as a template. The probe was eluted from the gel in $300 \mu$ l of elution buffer (Ambion/Bresatec, Australia) at $37^{\circ} \mathrm{C}$ for $2 \mathrm{~h}$ and radioactivity was measured in a sample of the eluate by scintillation counting.

\section{Tissue preparation for hybridization histochemistry}

All tissues were fixed for $24 \mathrm{~h}$ in $4 \%(\mathrm{w} / \mathrm{v})$ paraformaldehyde in $0.1 \mathrm{~mol}$ phosphate buffer $\mathrm{I}^{-1}\left(23 \mathrm{mmol} \mathrm{NaH} \mathrm{PO}_{4} \cdot 2 \mathrm{H}_{2} \mathrm{O}^{-1}\right.$ and $77 \mathrm{mmol} \mathrm{Na}_{2} \mathrm{HPO}_{4}$ anhydrous $\mathrm{l}^{-1}, \mathrm{pH} 7.2$ ), and then stored in $0.5 \mathrm{~mol}$ sucrose $\mathrm{l}^{-1}$ in $0.1 \mathrm{~mol}$ phosphate buffer $\mathrm{l}^{-1}$ at room temperature for $24 \mathrm{~h}$ (minimum) before dehydrating and wax embedding. Paraffin sections were cut at $5 \mu \mathrm{m}$, mounted onto aminoalkylsilane-treated slides (Rentrop et al., 1986), dewaxed and rehydrated through a graded series of alcohols.

Explanted blastocysts were prepared on the slides on which they were grown by treatment with the following reagents: pure acetone for $1 \mathrm{~min}$, followed by $4 \%$ paraformaldehyde in $0.1 \mathrm{~mol}$ phosphate buffer $\mathrm{l}^{-1}$ for $10 \mathrm{~min}$, with subsequent rinsing in distilled water and dehydration in three changes of $100 \%$ ethanol.

\section{Hybridization histochemistry}

The pretreatment of slides, constitution of hybridization buffer, formamide wash and method of hybridization were identical to that described by Senior et al. (1991).

Briefly, sections were pretreated with Pronase E (Sigma) and post-fixed in $4 \%$ paraformaldehyde in $0.1 \mathrm{~mol}$ phosphate buffer $1^{-1}$. They were then dehydrated, dried and used immediately. For hybridization, the labelled RNA probes ( $\mathrm{I} \mu \mathrm{Ci} \bumpeq 1.4 \mathrm{ng}$ RNA) were diluted to a concentration of $75 \mathrm{ng} \mathrm{ml}^{-1}$ in hybridization buffer, applied to slides and incubated overnight at $50^{\circ} \mathrm{C}$. The slides were then washed in three changes of formamide wash solution at $50^{\circ} \mathrm{C}$, digested with RNAse $\left(150 \mu \mathrm{g} \mathrm{ml}^{-1}\right.$, Sigma) and washed twice in $2 \times$ standard saline citrate at $65^{\circ} \mathrm{C}$. They were then dehydrated through a graded series of alcohols and exposed to X-ray film (X-OMAT AR; Eastman Kodak, Rochester, NY) for $48 \mathrm{~h}$ to assess strength of labelling. All slides were dipped in K5 (Ilford, Mobberley) liquid emulsion and exposed for 4-6 days before developing and staining with haematoxylin or haematoxylin and eosin omitting the differentiation step using acid alcohol.

\section{Induction of deciduomata}

Female Sprague-Dawley rats were mated with vasectomized males and pseudopregnancy was timed from midnight on the night before the demonstration of a vaginal plug. At day 4.5 of pseudopregnancy between 0.5 and $0.75 \mathrm{ml}$ of corn oil was injected into the left uterine horn of animals anaesthetized with $0.1 \mathrm{ml} 100 \mathrm{~g}^{-1}$ Nembutal (Boeringer Ingelheim, Artamon, NSW) between two ties placed at the extreme ovarian and cervical ends. The right horn of the uterus served as a control. Animals were killed with Lethobarb at 3, 6, 24, 72, 96 and $120 \mathrm{~h}$ after injection; in all cases a thickening of the uterine wall indicative of the development of a decidual reaction could be seen $96 \mathrm{~h}$ after injection and in the majority this was apparent after $72 \mathrm{~h}$. Control and injected horns were fixed in paraformaldehyde and processed as described above.

In another series of animals a laparotomy was performed and the left horn of the uterus was tied at its ovarian and cervical extremities. Between I and 3 months later these animals were mated with normal males and pregnancy was timed from midnight of the night preceding the demonstration of a vaginal plug. Between 0.5 and $0.75 \mathrm{ml}$ of corn oil was injected into the left uterine horn at 4.5 days after mating and animals were killed with Lethobarb $96 \mathrm{~h}$ after injection. The normally pregnant right uterine horn was taken as a control. Although a 
decidual reaction similar to that produced after mating with vasectomized males was produced in all cases, it was found at the time of oil injection that the tied uterine horn was grossly distended by uterine secretions. For this reason, the majority of experiments were performed on pseudopregnant females following mating with vasectomized males.

\section{Blastocyst culture}

At day 4.5 of gestation (timed, as above, from demonstration of vaginal plug), blastocysts were flushed from the uteri of pregnant Sprague-Dawley rats with blastocyst culture medium. They were then explanted into Lab-Tek chamber slides (Nunc Inc., Naperville, Illinois) and cultured for 7 days, either directly on the glass slide or on a feeder layer of immortalized mitomycintreated fibroblasts (STO cells) (Robertson, 1987). The culture medium used was as described by Robertson (1987). At the end of the culture period, differentiated trophoblastic giant cells had spread out from around a central core of undifferentiated inner cell mass cells. The preparations were then fixed for hybridization histochemistry as described above.

\section{RNA preparation}

Tissues were taken immediately post-mortem and stored in liquid nitrogen until required.

Total RNA was prepared by the method of Chomczynski and Sacchi (1987). Briefly, up to $1 \mathrm{~g}$ tissue was homogenized in $10 \mathrm{ml} 4 \mathrm{~mol}$ guanidinium isothyocyanate $\mathrm{l}^{-1}$. Sodium citrate (25 mmol 1-1, $\mathrm{pH} 7.5$ ), $0.1 \mathrm{~mol} \beta$-mercaptoethanol $\mathrm{1}^{-1}, 0.5 \%$ sodium sarkosyl, sodium acetate ( $1.5 \mathrm{ml}$ of $2 \mathrm{~mol} \mathrm{I}^{-1}, \mathrm{pH} 4.5$ ), $10 \mathrm{ml}$ of phenol equilibrated with diethyl pyrocarbonate (DEPC)-treated water and $4 \mathrm{ml}$ of chloroform:isoamyl alcohol $(25: 1 \mathrm{v} / \mathrm{v})$ were then added. After thorough mixing by inversion ( $5 \mathrm{~min}$ ) the phases were separated by centrifugation (10 $000 \mathrm{~g}$ for $15 \mathrm{~min}$ ). The aqueous phase was retained and the RNA precipitated by the addition of an equal volume of isopropanol and centrifugation (10000 $\mathrm{g} 20 \mathrm{~min}$ ); the pellet was then resuspended in $5 \mathrm{ml}$ homogenization buffer at $65^{\circ} \mathrm{C}$. The RNA was then again precipitated with salt and ethanol, recovered by centrifugation (10000 $\mathrm{g}$ for $10 \mathrm{~min}$ ) and resuspended in $1 \mathrm{ml}$

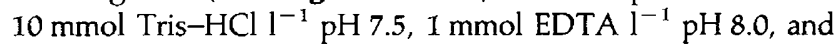
$0.1 \%$ sodium dodecyl sulfate. The yield of RNA was determined spectrophotometrically and its integrity determined by electrophoresis in agarose gels containing formaldehyde (Sambrook et al., 1989). The RNA was stored at $-80^{\circ} \mathrm{C}$.

\section{RNAse protection}

RNAse protection was carried out using an Ambion kit and following the manufacturer's protocol. Briefly, about $10 \mu \mathrm{g}$ of each of the total RNA samples was mixed with $2 \times 10^{5}$ c.p.m. of either the PTHrP or $\beta$-actin ${ }^{32} \mathrm{P}$-labelled anti-sense probe, in a total volume of $100 \mu \mathrm{l}$. One hundred microlitres of $4 \mathrm{~mol}$ $\mathrm{NH}_{4} \mathrm{Ac} \mathrm{l}^{-1}$ and $500 \mu \mathrm{l}$ of absolute ethanol were added. The samples were mixed and centrifuged for $15 \mathrm{~min}$ at $11600 \mathrm{~g}$. The supernatant was discarded and the pellet resuspended in hybridization buffer (Ambion/Bresatec, Australia), and heated at $95^{\circ} \mathrm{C}$ for $4 \mathrm{~min}$. The samples were then incubated for $16 \mathrm{~h}$ at $42^{\circ} \mathrm{C}$. The RNAse A/Ti solutions provided were diluted 1:100 with RNAse buffer and $200 \mu \mathrm{l}$ added to each sample. The samples were digested for $30 \mathrm{~min}$ at $37^{\circ} \mathrm{C}$. The samples were precipitated with the solution provided and, after centrifugation (11 $600 \mathrm{~g} 15 \mathrm{~min})$, the pellets were resuspended in $8 \mu \mathrm{l}$ loading buffer. Two microlitres of each sample was run on a $6 \%$ polyacrylamide gel. After electrophoresis, the gel was dried and autoradiographed.

\section{Results}

\section{PTHrP expression during normal pregnancy}

PTHrP mRNA could not be demonstrated by hybridization histochemistry until day 5.5 of gestation. At this stage a decidual reaction begins anti-mesometrially in the connective tissue stroma of circumscribed sites at which blastocysts are implanting (Enders and Schlafke, 1967). The epithelial cells in this region become morphologically distinct; they are columnar rather than cuboidal with spherical or ovoid decondensed nuclei and an increased nucleo:cytoplasmic ratio. These cells hybridize strongly with the PTHrP anti-sense probe. There is a sudden cut-off point between them and adjacent non-hybridizing epithelial cells; weakly reactive cells are not seen (Figs 1,2 ). The underlying decidual cells did not hybridize with the probe at this stage, neither did the non-decidual uterine stroma nor the surrounding smooth muscle. The blastocyst at this stage was also negative.

At day 6.5 the anti-mesometrial epithelial cells have disappeared and trophoblast cells lie against their residual basement membrane. At the extreme anti-mesometrial pole, a few sloughed epithelial cells may be seen in what remains of the original crypt uterine lumen. Trophoblast cells have not yet differentiated into the typical giant cells seen at later stages. Hybridization histochemistry with PTHrP anti-sense indicates that no positively hybridizing cells are present at this stage. Thus, neither the trophoblast nor the decidua have started transcribing the PTHrP gene at a level demonstrable by hybridization histochemistry.

A positive reaction becomes apparent in the trophoblastic giant cells at day 7.5 and persists in the region surrounding the implantation site until day 12.5. By day 13.5 it has disappeared. Positive cells were often found deep in the decidual tissue and, although it is difficult to determine whether these are of trophoblastic or decidual origin, examination of the available material suggested that a considerable proportion of the positively hybridizing cells were decidual (Fig. 3). This conclusion was supported by the results of the deciduoma experiments described below.

At days 15.5 and 18.5, a low level of hybridization was seen in the myometrium at sites of uterine occupancy. Isolated cells in the muscle layer were distinctly positive, but the majority did not react. It was not possible to distinguish positively reacting cells on morphological grounds alone. At day 20.5 both the number of cells and the intensity with which they hybridized had increased considerably (Fig. 4), although the majority of myometrial cells still remained unreactive.

\section{PTHrP expression in experimentally produced deciduoma}

Injection of $1 \mathrm{ml}$ of corn oil into the left horn of a pseudopregnant rat consistently produced a deciduomal reaction in the 

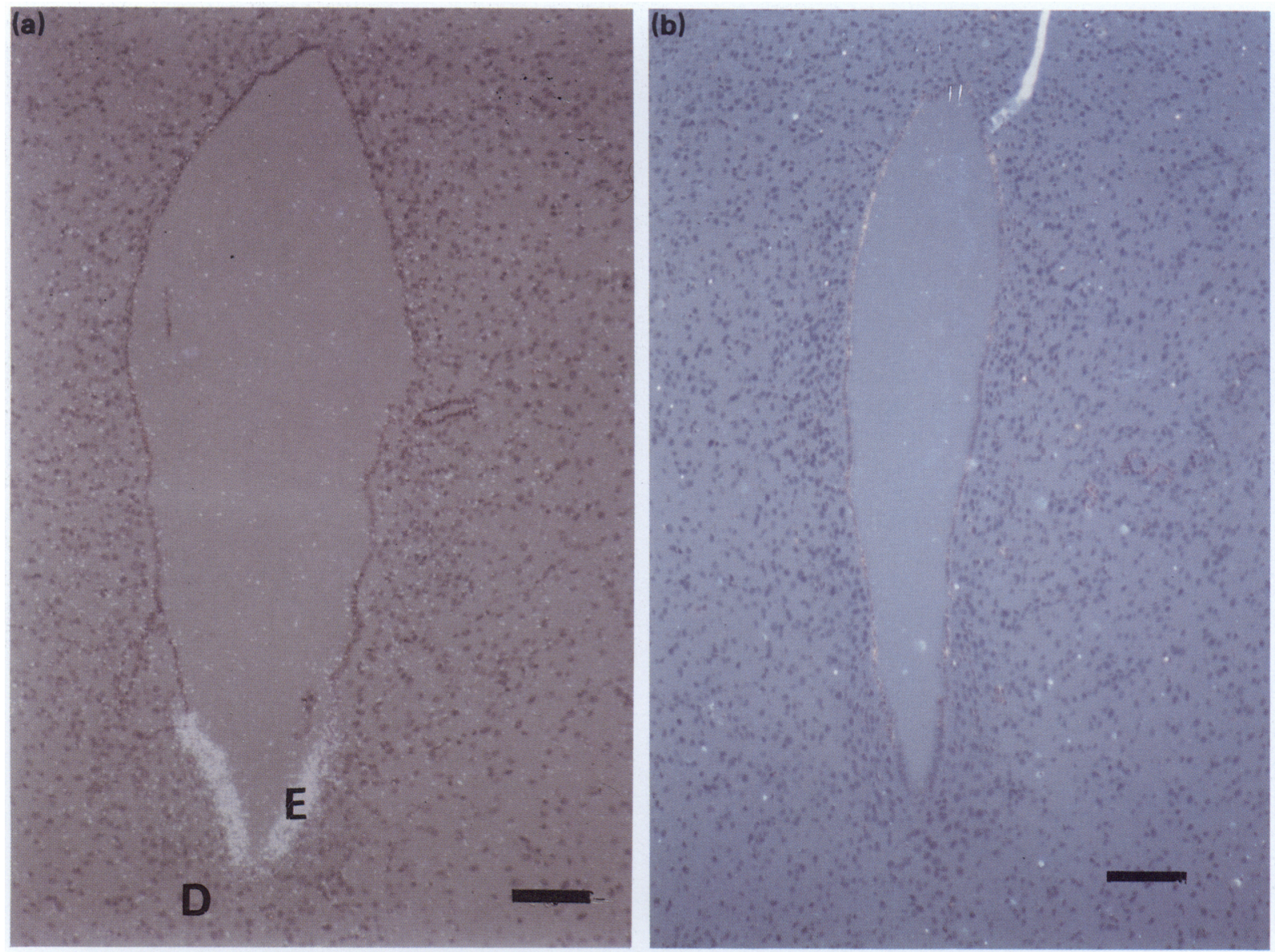

Fig. 1. Transverse section through day 5.5 pregnant rat uterus in the region of an implantation site showing strong hybridization in the epithelium (E) at the anti-mesometrial pole. Early decidualization (D) is occurring deep to the anti-mesometrial epithelium indicating that the uterine section is in the region of an attachment site. The decidual cells, at this stage, are negative. Haematoxylin stain. (a) Bright field/dark field double exposure anti-sense probe. (b) Bright field/dark field double exposure sense probe. Scale bars $=85 \mu \mathrm{m}$.

classical manner described by Hetherington (1968). No changes were seen in the right (control) horn and no hybridization with the PTHrP probe was observed in this horn at any of the stages studied.

Within $3 \mathrm{~h}$ of oil injection, the epithelial lining of the uterine cavity hybridized weakly with the PTHrP probe (Fig. 5). No reaction was detectable in the epithelium of the uterine glands.

Six hours after oil injection, a very strong reaction, confined to the uterine epithelium, was produced while the underlying stromal cells, which had not yet become decidualized, remained negative. The luminal epithelium had hybridized more strongly at the anti-mesometrial pole than in the mesometrial region (Fig. 6) but the epithelial lining of the uterine glands remained negative.

Twenty-four hours after injection, the epithelium at the antimesometrial pole remained distinctly positive, while the remainder of the epithelium no longer expressed the gene. Again, there was no evidence of hybridization in the uterine stroma. Stromal cells had not yet adopted a distinctly decidual phenotype, although the first histological evidence of a deciduomal reaction to corn oil was detectable anti-mesometrially.

Seventy-two hours after injection, a distinct decidual reaction was visible, but the decidualized cells did not show PTHrP gene expression. Furthermore, the epithelial cells had also ceased to show a positive hybridization reaction.

Ninety-six hours after injection (day 8.5 of pseudopregnancy) the decidual reaction had increased in size and some of its component cells expressed the PTHrP gene strongly. The epithelial lining of the uterine lumen though completely intact continued to be PTHrP negative.

At $120 \mathrm{~h}$ after injection (day 9.5 of pseudopregnancy) a strong positive reaction was apparent in a large proportion of the decidual cells (Fig. 7) surrounding the uterine lumen. At this time also, the myometrium was strongly positive. This contrasts with the situation observed at day 9.5 of a normal gestation in which myometrial PTHrP mRNA is too low to be detected by hybridization histochemistry. The difference may be due to the greater luminal distension in the oil-injected uterus compared with the day 9.5 pregnant uterus.

The time of appearance of a positive reaction in the deciduoma cells corresponds well to observations in normal pregnancy, that is at days 7.5 and 8.5 of true pregnancy and pseudopregnancy, respectively. In each case, there was preceding expression in the anti-mesometrial uterine epithelium which ceased about a day before the decidual cells began to express the message. 

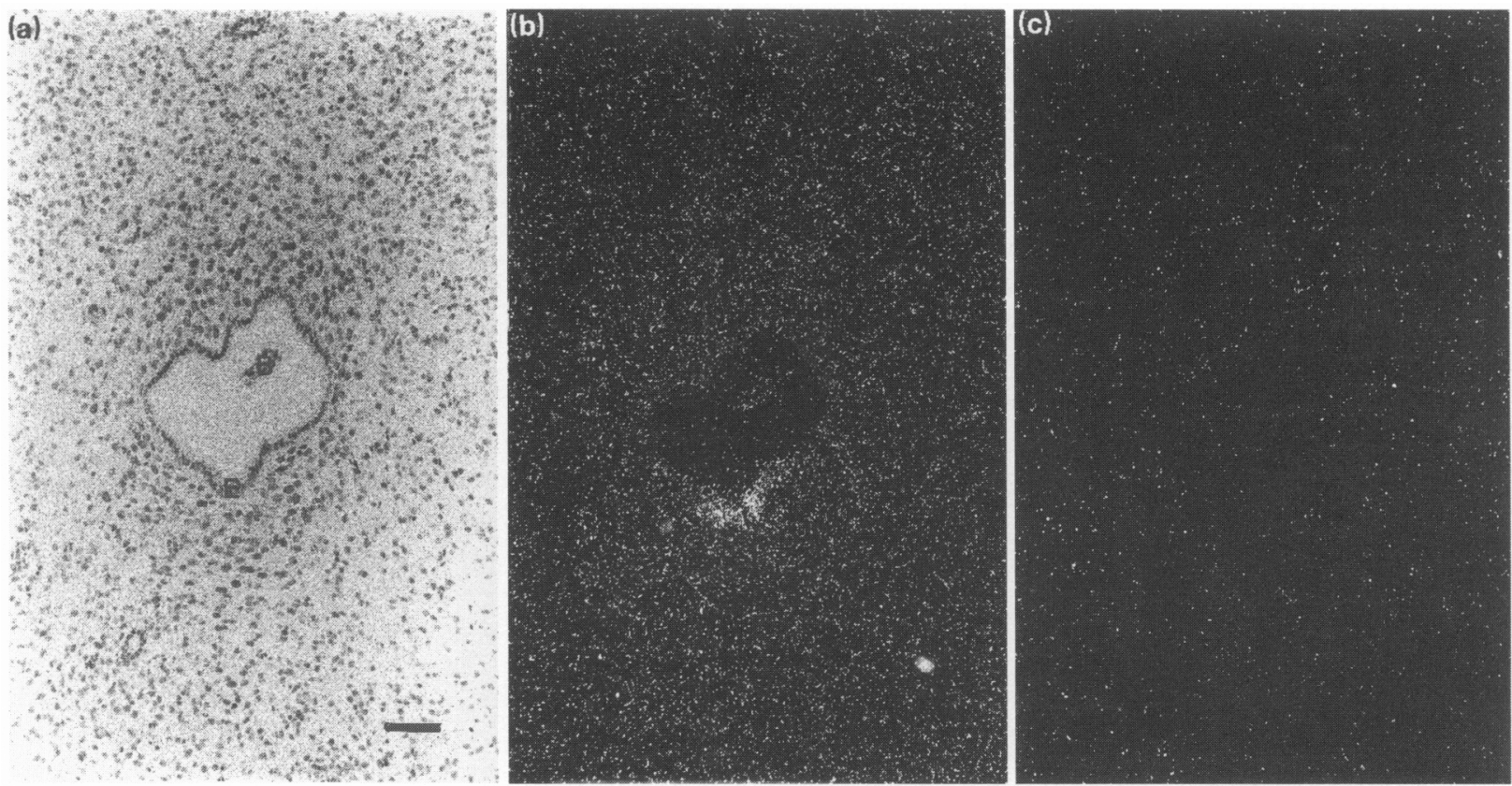

Fig. 2. Oblique section through anti-mesometrial region of the rat uterus at day 5.5 of gestation showing blastocyst (B) which may have become detached from the uterus during processing. The anti-mesometrial epithelium (E) towards the base shows positive hybridization with the parathyroid hormone-related protein (PTHrP) anti-sense but the blastocyst itself and the surrounding decidua is negative. PTHrP anti-sense probe, haematoxylin stain. (a) Bright field. (b) Dark field anti-sense probe. (c) Dark field sense probe. The photograph of the slide hybridized with the sense probe was scanned through a Kodak RFS2035 film scanner. Using Adobe Photoshop Software, a new negative was made in which large birefringent artefacts were removed. All silver grains of sizes compatible with the effects of ${ }^{35} \mathrm{~S}$ were retained. Scale bar $=60 \mu \mathrm{m}$.
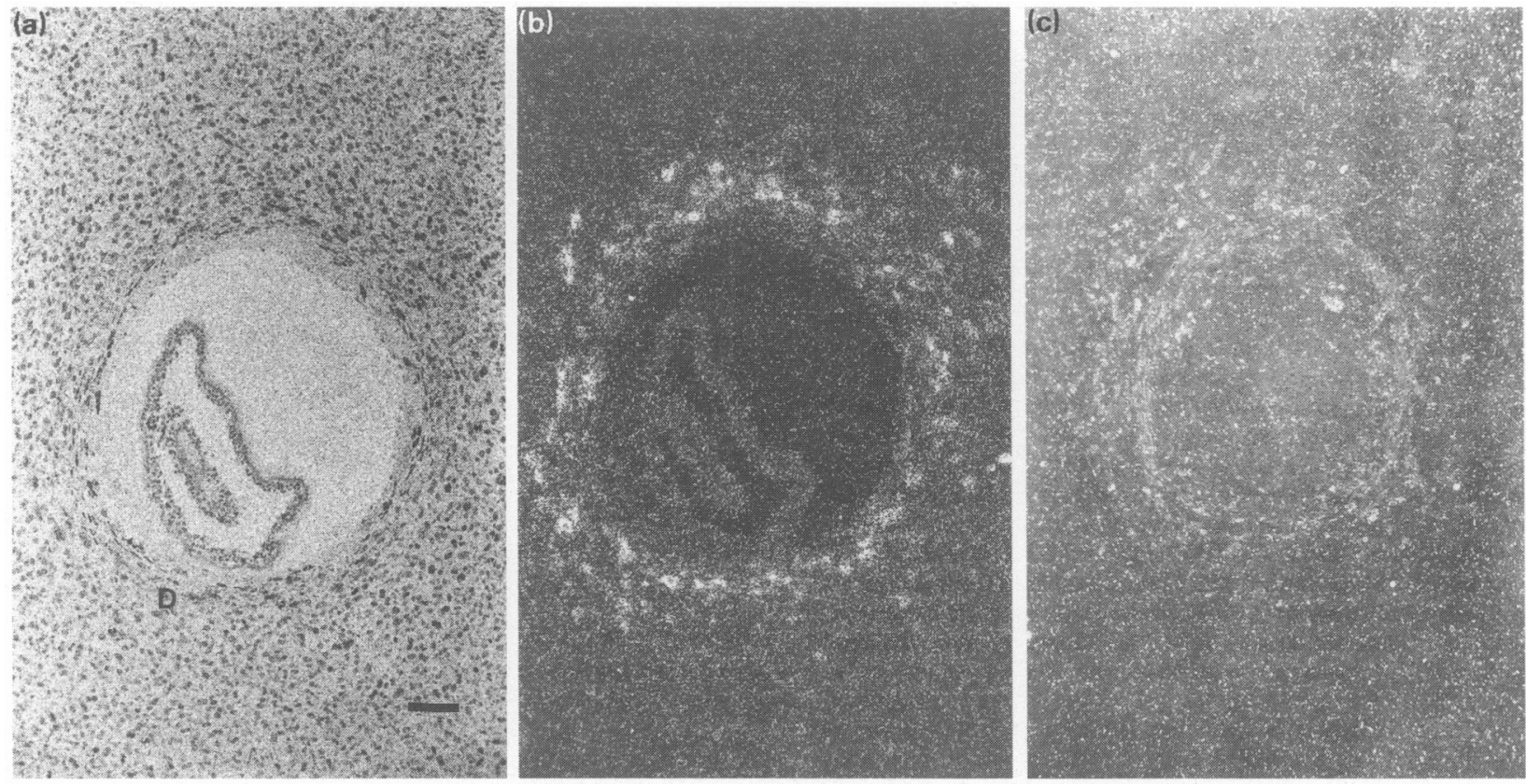

Fig. 3. Transverse section through implantation chamber containing an embryo at day 9.5 of gestation. Strong hybridization is apparent in decidual cells (D), particularly those compressed by the implanting conceptus. Parathyroid hormone-related protein (PTHrP) anti-sense probe, haematoxylin stain. (a) Bright field. (b) Dark field. (c) Dark field sense probe control. Scale bar $=140 \mu \mathrm{m}$. 

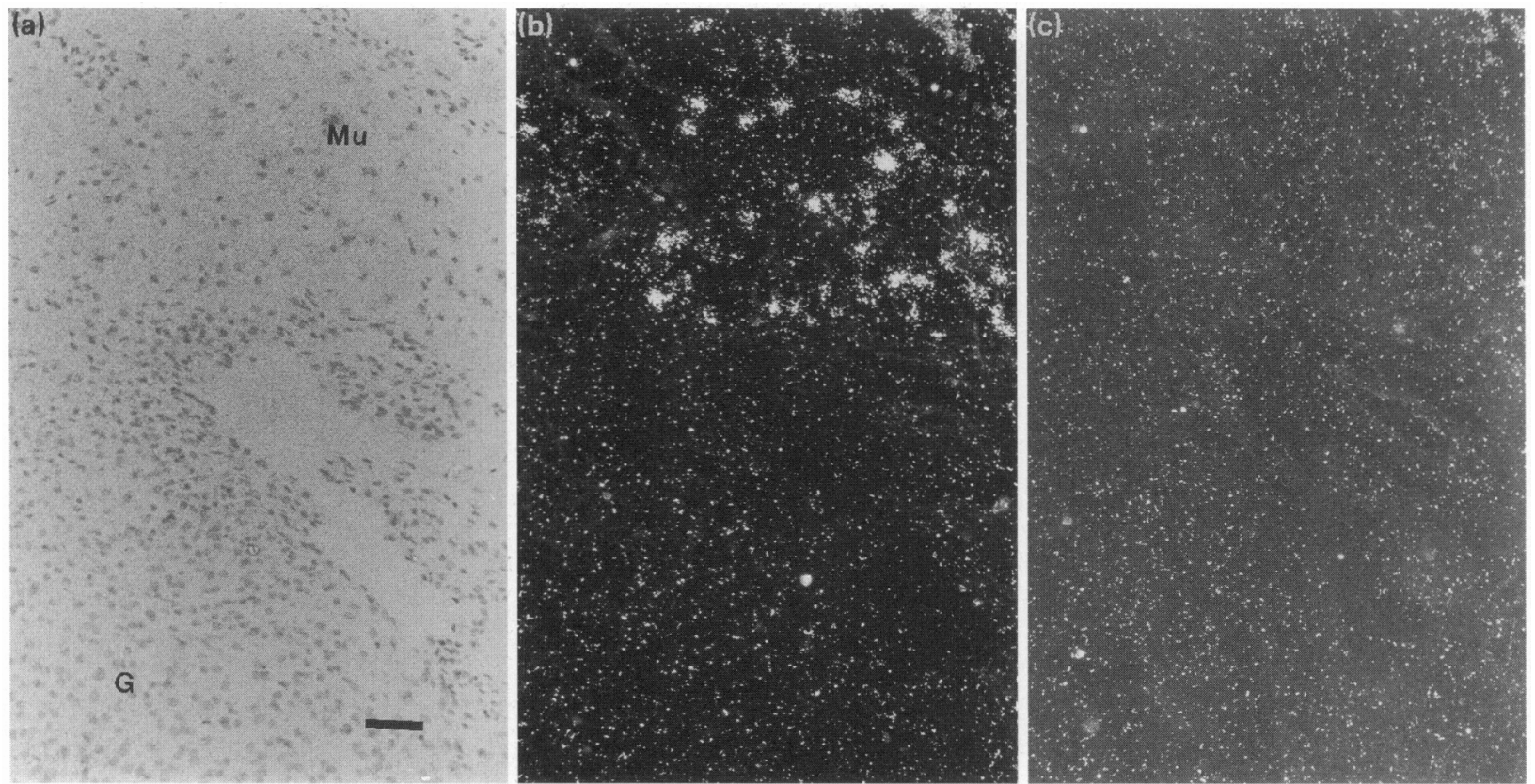

Fig. 4. Section through the regressing metrial gland area $(G)$ and adjacent uterine musculature $(M u)$ in day 20.5 pregnant rat uterus Scattered cells in the muscularis hybridize strongly with the parathyroid hormone-related protein (PTHrP) probe. The cells in the metrial gland region are entirely negative. PTHrP anti-sense probe, haematoxylin stain. (a) Bright field. (b) Dark field. (c) Dark field sense probe control. Scale bar $=80 \mu \mathrm{m}$
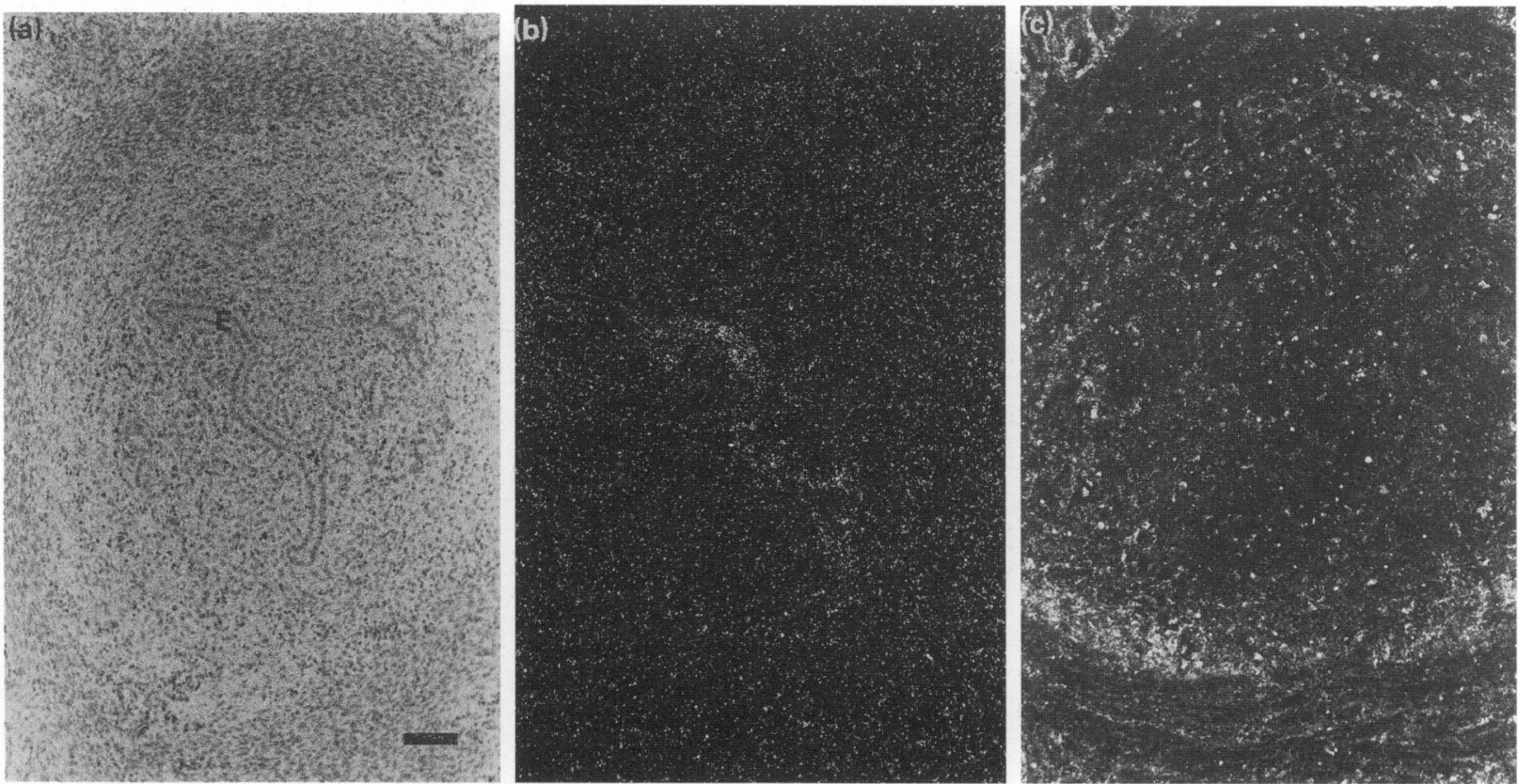

Fig. 5. Section through the uterine lumen of a day 4.5 pseudopregnant rat $3 \mathrm{~h}$ after injection of corn oil into the uterine cavity. A low level of hybridization in the endometrial epithelium (E) is apparent. Parathyroid hormone-related protein (PTHrP) anti-sense probe, haematoxylin stain. (a) Bright field. (b) Dark field. (c) Dark field sense probe control. The photograph of the slide hybridized with the sense probe was scanned through a Kodak RFS2035 film scanner. Using Adobe Photoshop Software, a new negative was made in which large birefringent artefacts were removed. All silver grains of sizes compatible with the effects of "S were retained. Scale bar $=110 \mu \mathrm{m}$. 

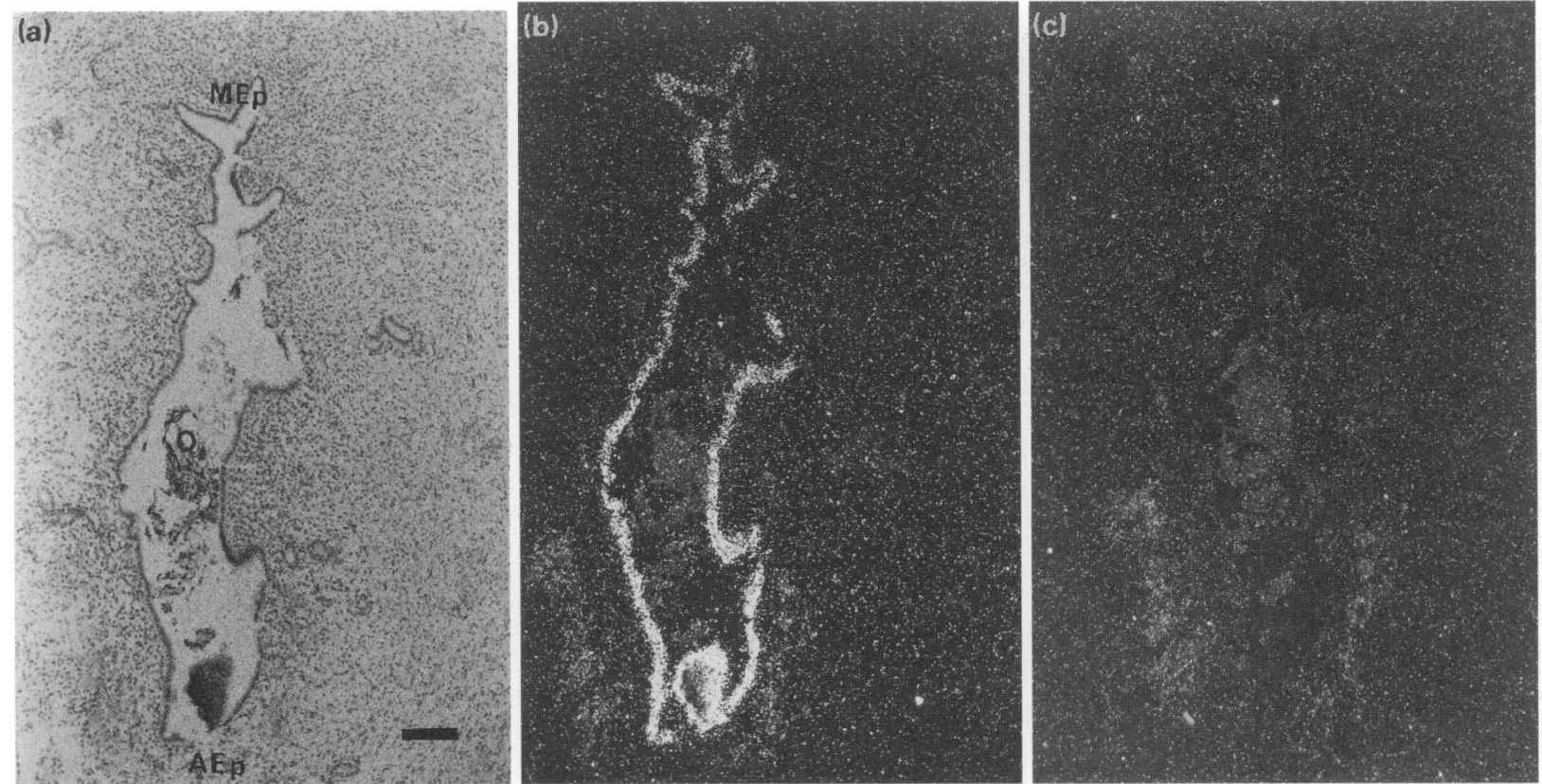

Fig. 6. Section through the uterine lumen of a day 4.75 pseudopregnant rat $6 \mathrm{~h}$ after injection of corn oil $(\mathrm{O})$ into the uterine cavity. A much higher level of hybridization than was seen $3 \mathrm{~h}$ after injection (cf. Fig. 5) is now demonstrable in the epithelium. The anti-mesometrial epithelium (AEp) hybridizes more strongly than that at the mesometrial pole (MEp). Parathyroid hormone-related protein (PTHrP) anti-sense probe, haematoxylin and eosin stain. (a) Bright field. (b) Dark field. (c) Dark field sense probe control. Scale bar $=140 \mu \mathrm{m}$.
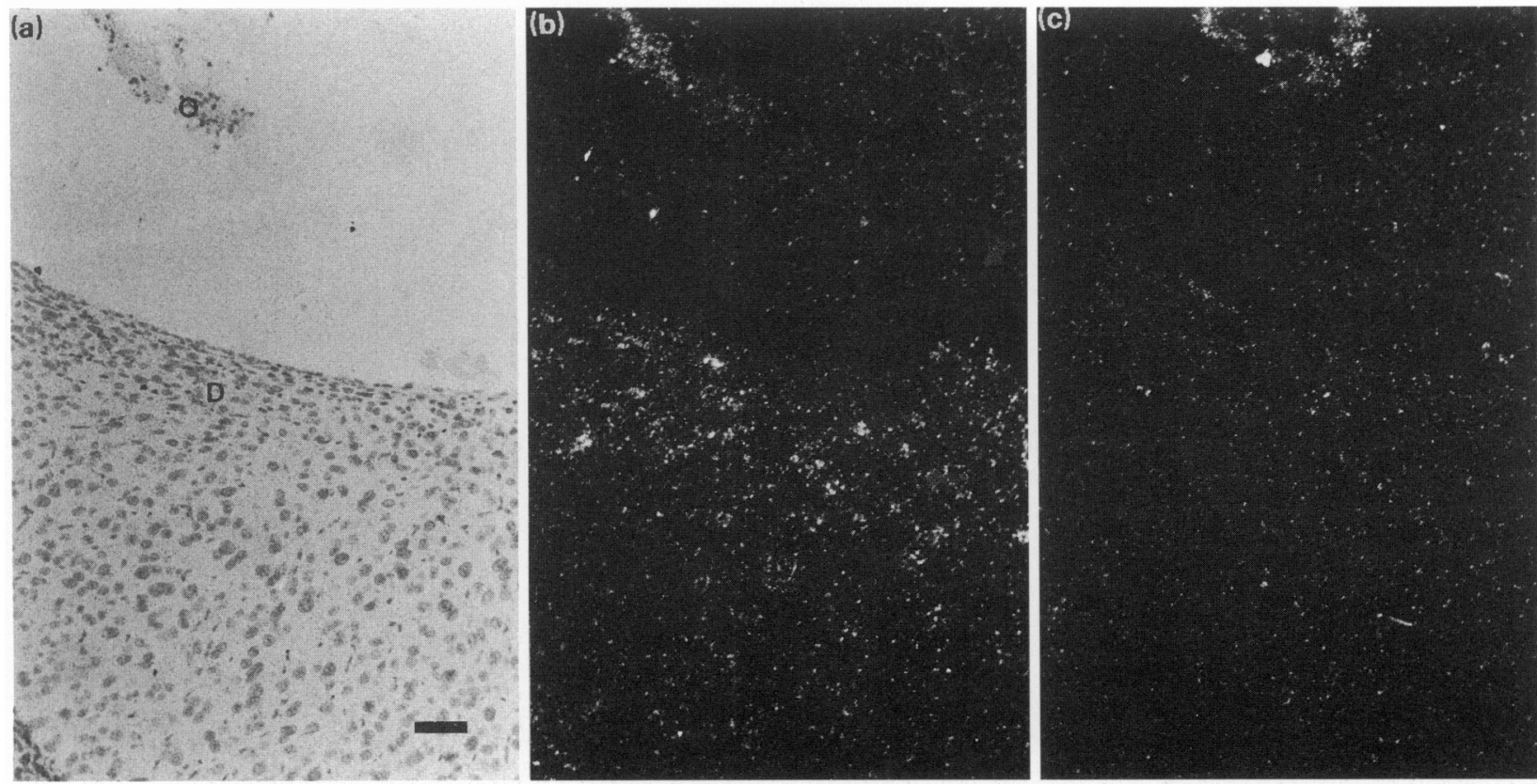

Fig. 7. Section through uterine lumen of a day 9.5 pseudopregnant rat 5 days after injection of corn oil (O) into the uterine cavity. Many of the cells of the oil-induced deciduoma (D) hybridize strongly with the parathyroid hormone-related protein (PTHrP) probe. PTHrP anti-sense probe, haematoxylin stain. (a) Bright field. (b) Dark field. (c) Dark field sense probe control. Scale bar $=70 \mu \mathrm{m}$.

\section{PTHrP expression in explanted blastocysts}

Seven days after explantation directly onto glass slides or onto a feeder layer of STO cells, blastocysts had differentiated morphologically into a central mass of cells that were principally of inner cell mass origin surrounded by an outgrowing 'halo' of trophoblastic giant cells. This is the appearance described by Robertson (1987) in mice when using this technique for isolating and culturing embryonic stem cells. Hybridization histochemistry performed on whole mounts of such preparations clearly showed that trophoblastic giant cells reacted with the PTHrP probe, whereas the cells of the feeder 

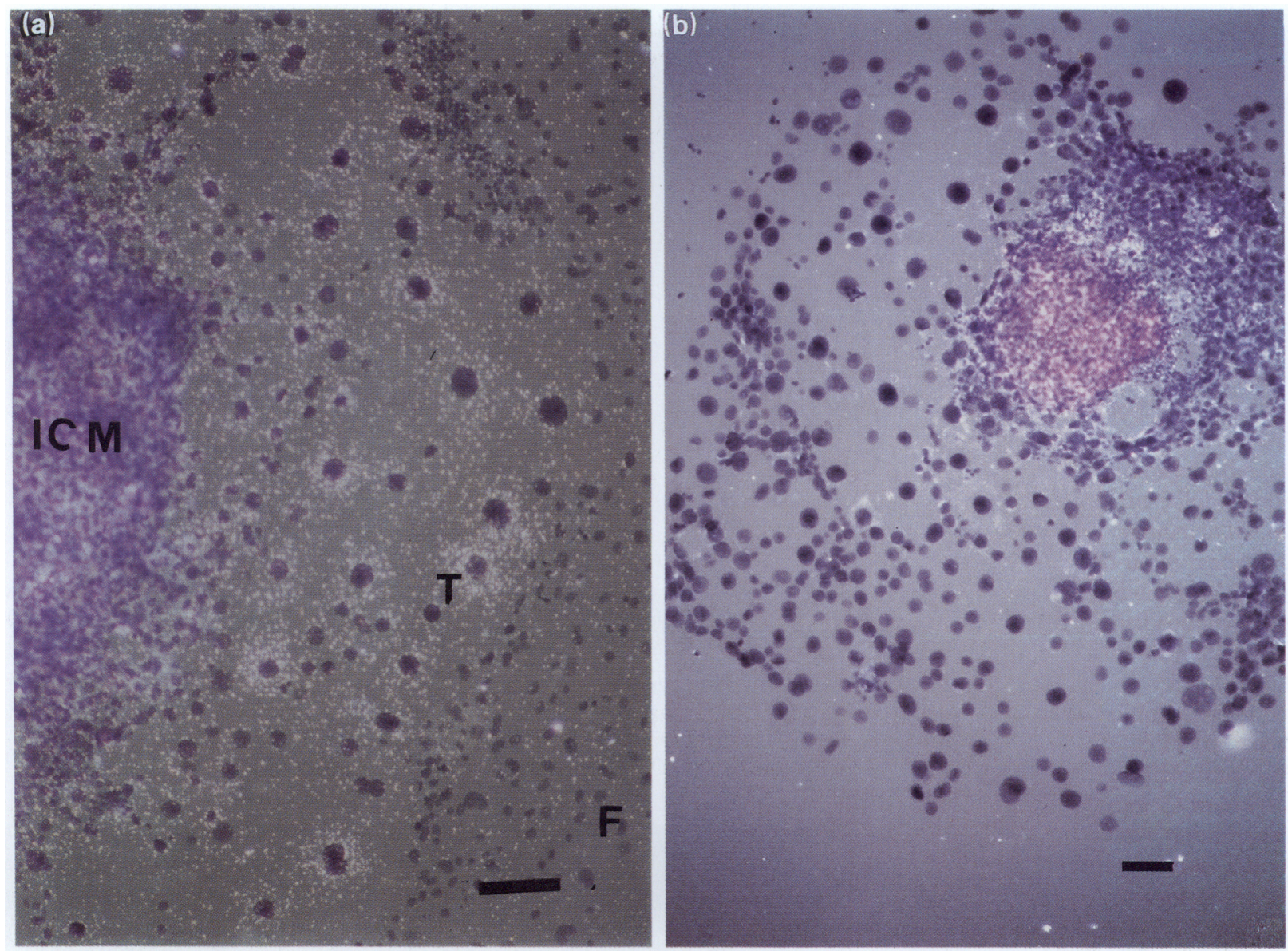

Fig. 8. Whole mount showing the edge of an explanted blastocyst grown on a feeder layer of STO cells. The trophoblastic giant cells (T) at the edge of the explant have hybridized with the PTHrP probe. The cells of the feeder layer (F) are negative. ICM: inner cell mass; parathyroid hormone-related protein $(\mathrm{PTHr}$ ) anti-sense probe, haematoxylin stain. (a) Bright field/dark field double exposure. (b) Bright field/dark field double exposure sense probe control. Scale bar $=150 \mu \mathrm{m}$.

layer of STO cells remained negative (Fig. 8). Some silver deposit was seen over the inner cell mass; this did not take the form of discrete silver grains and was probably an artefact caused by the heaping up of the inner cell mass accumulation; it was also seen on sections hybridized with the sense probe.

\section{RNAse protection}

The presence of authentic PTHrP mRNA in tissues which were positive by hybridization histochemistry was confirmed by RNAse protection. The probe, which is to the coding region, should detect all authentic PTHrP messenger RNA. RNA isolated from lactating mammary gland, decidual masses removed at day 9.5 of normal gestation, deciduomata produced $120 \mathrm{~h}$ after oil injection, muscle surrounding $120 \mathrm{~h}$ deciduomata and muscle from a uterine occupancy site at day 19.5 of gestation all stained positively. A low level of transcript was also detectable in the control (uninjected) uterine horn from animals $120 \mathrm{~h}$ after oil injection into the contralateral horn (Fig. 9). In each case a single protected band corresponding to the full length (330 bases) of the ${ }^{32} \mathrm{P}$-labelled anti-sense PTHrP RNA probe used was detected. Lactating mammary gland is widely accepted as a standard reference tissue in which transcription and translation of the PTHrP gene occurs as part of normal function (Thiede and Rodan, 1988; Thiede, 1989).

\section{Discussion}

The earliest evidence of pregnancy related expression of the $\mathrm{PTHrP}$ gene appears at day 5.5 in the anti-mesometrial uterine epithelium at implantation sites. The remainder of the uterine epithelium and that lining the uterine glands does not hybridize with the probe. Paspaliaris et al. (1992) demonstrated the presence of PTHrP mRNA in the uterine epithelium of oestrogen treated immature rats, but the hybridization they showed also involved the myometrium and, to some extent, the uterine stroma; furthermore, the epithelial reaction they described was not localized to a defined topographical region. Thiede et al. (1991) also showed upregulation of PTHrP mRNA in vivo in the nonpregnant rat uterus by oestradiol. Other factors, including epidermal growth factor (Rodan et al., 1989), TGF- $\beta$ (Kiriyama et al., 1991; Casey et al., 1992) and prolactin (Thiede, 1989) upregulate gene expression in various situations, whereas 


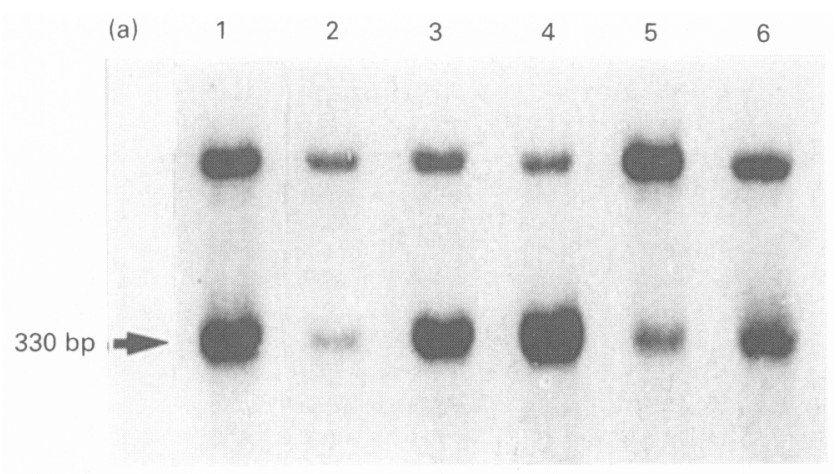

PTHrP

(b)

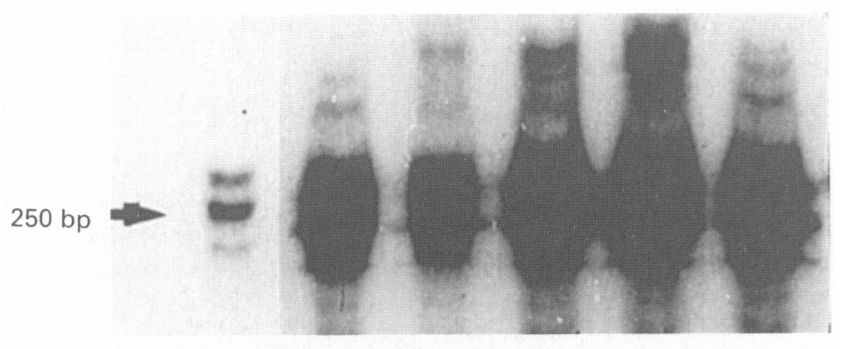

$\beta$-Actin

Fig. 9. RNAase protection gel. Lane 1: RNA from lactating rat mammary gland. Lane 2: RNA from control (pseudopregnant) uterine horn, not injected with oil. Lane 3: RNA from uterine muscle from uterine horn of pseudopregnant rat $120 \mathrm{~h}$ after injection with corn oil. Lane 4: RNA from the decidual mass of a normal 9.5 day pregnancy. Lane 5: RNA from a deciduoma 120 hours after injection of corn oil. Lane 6 : RNA from uterine muscle surrounding 19.5 day fetuses. (a) Ten microgrammes of each total RNA hybridized with PTHrP probe, a protected band of 330 bases corresponding to PTHrP mRNA is present to a greater or lesser degree in all samples. The second (upper) band is due to protection of the full length probe (which contains 76 bases of RNA derived from the plasmid vector in addition to the 330 bases of PTHrP sequence) by residual undigested DNA template, a common occurrence in this assay (Sambrook et al., 1989). Four day exposure $-70^{\circ} \mathrm{C}$ with intensifying screens. (b) Ten microgrammes of each RNA hybridized to the $\beta$-actin probe to indicate relative loading of RNA. Exposure for $18 \mathrm{~h}$ at $-70^{\circ} \mathrm{C}$ with intensifying screens.

vitamin D and dexamethasone (Ikeda et al., 1989; Lu et al., 1989) have the opposite effect. The pattern we observed at the time of implantation was, therefore, almost certainly the result of an interplay involving numerous tissue specific enhancers or inhibitors in addition to oestrogen.

The biological role of $\mathrm{PTHrP}$ at this stage of gestation is not established, but its precise limitation to epithelial cells at implantation sites suggests that it plays a part in the localization of implantation or initial decidualization in addition to any possible function of inhibiting the uterine musculature. We were also able to stimulate gene transcription in the epithelium within $3 \mathrm{~h}$ of intrauterine injection of corn oil at day 4.5 of pseudopregnancy. Although expression was not as precisely localized as in normal pregnancy, the result adds credence to the suggestion that the action of PTHrP is important at the epithelial site of blastocyst implantation.
At 6.5 days, PTHrP mRNA cannot be detected at uterine implantation sites. Since the half-life of the secreted protein is short and there is no evidence of intracellular storage, it seems likely that there is no requirement for the hormone at this stage of pregnancy. As described by Senior et al. (1991), gene transcription had recommenced by day 7.5 and was located in trophoblastic giant cells, as well as in decidual cells. The gene was not uniformly transcribed in all the cells belonging to each of these cell populations. Instead, some cells hybridized particularly strongly - especially individual or groups of decidual cells adjacent to the implantation site, whereas other cells remained negative. These observations suggest that PTHrP has a local role in the maintenance of pregnancy after blastocyst implantation and that this remains important until day 13 when mRNA can no longer be detected in the extraembryonic membranes by hybridization histochemistry.

The detection of PTHrP mRNA in experimentally produced deciduomata both by hybridization histochemistry and RNase protection proves that some of the positive cells observed in normal pregnancy are indeed decidual in origin and, furthermore, that the presence of a blastocyst is not necessary for the induction of transcription in decidual cells. The location of the most strongly positive cells to around the uterine lumen in both deciduomata and normal pregnancy suggests that in both situations the original stimulus might occur via a transduction mechanism involving the epithelium. Among the challenging questions remaining are the nature of the molecular mechanism responsible for the induction of gene transcription and the physiological role of PTHrP secretion at this site. In control experiments, comparable to those performed on pseudopregnant animals we could not detect localized PTHrP mRNA by hybridization histochemistry in the uterus of normally cyclic rats at any time in the 5 days following oil injection into the lumen (results not shown).

Towards the end of gestation the PTHrP gene is transcribed in both the circular and the longitudinal smooth muscle layer of the uterus. Once again, expression is confined to isolated cells or small groups of cells, whereas other cells remain negative. We were unable to characterize the positive cells by any obvious morphological criterion. A more exhaustive series of experiments is necessary to indicate whether the cells involved are muscle cells with growth or contractile characteristics which differ from the remainder. Myometrial localization of PTHrP mRNA has been described by Thiede et al. (1990). Parathyroid hormone and PTHrP inhibit smooth muscle contractility and it appears that uterine smooth muscle is especially sensitive to the peptide (Paspaliaris et al., 1992). Smooth muscle cells in the wall of the uterine blood vessels did not appear to hybridize.

After explantation of the rat blastocysts onto glass slides or onto a feeder layer of STO cells, differentiation and outgrowth of trophoblastic giant cells around the inner cell mass occurred. The trophoblastic cells contained PTHrP mRNA, whereas those of the inner cell mass did not at the level demonstrable by hybridization histochemistry. Before implantation all the cells of the blastocyst were negative. It seems, therefore, that differentiation into trophoblastic giant cells involves either a switch on or a very strong upregulation of PTHrP gene transcription. Taken together with the gene expression demonstrable in decidual cells, these results underline the apparent involvement of PTHrP in the maintenance of the newly implanted blastocyst. 
They also indicate that some of the positive cells demonstrable at implantation sites in normal pregnancies are trophoblastic.

The authors are grateful to A. Russell and M. Kafali for their excellent technical assistance. The cDNA used to prepare the probe for hybridization histochemistry was identical to that provided by $M$. Thiede for our previous publications and we again wish to express our thanks. This work is supported by an Institute block grant from National Health and Medical Research Council. P. V. Senior is an R. Douglas Wright Fellow of the National Health and Medical Research Council.

\section{References}

Burtis WJ, Wu J, Bunch CM, Wysolmerski JJ, Insogna KI, Weir EC, Broadus AE and Stewart AF (1987) Identification of a novel 17,000-dalton parathyroid hormone-like adenylate cyclase-stimulating protein from a tumour associated with humoral hypercalcaemia of malignancy The Joumal of Biological Chemistry 262 7151-7156

Campos RV, Asa SL and Drucker DJ (1991) Immunocytochemical localisation of parathyroid hormone-like peptide in the rat fetus Cancer Research 51 $6351-6357$

Casey ML, Mibe M, Erk A and MacDonald PC (1992) Transforming growth factor- $\beta$, stimulation of parathyroid hormone-related protein expression in human uterine cells in culture: mRNA levels and protein secretion Journal of Clinical Endocrinology and Metabolism 74 950-952

Chomczynski P and Sacchi N (1987) Single step method of RNA isolation by acid guanidinium thiocyanate-phenol-chloroform extraction Analytical Biochemistry 162 156-159

Enders AE and Schlafke S (1967) A morphological analysis of the early implantation stages in the rat American Joumal of Anatomy 120 185-226

Ernst M, Rodan GA and Thiede MA (1989) Rapid induction of parathyroid hormone-like peptide (PTH-LP) in keratinocytes: implication of PTH-LP in the proliferative response to epidermal growth factor Joumal of Bone and Mineral Research 4 (Supplement I) A309

Hetherington CM (1968) The development of deciduomata induced by two non-traumatic methods in the mouse Journal of Reproduction and Fertility 17 391-393

Ikeda K, Weir EC, Mangin M, Dannies PS, Kinder B, Deftos, LJ, Brown EM and Broadus AE (1988) Expression of messenger ribonucleic acids encoding a parathyroid hormone-like peptide in normal human and animal tissues with abnormal expression in human parathyroid adenomas Molecular Endocrinology 2 1230-1236

Ikeda K, Lu C, Weir EC, Mangin M and Broadus AE (1989) Transcriptional regulation of the parathyroid hormone-related peptide gene by glucocorticoids and vitamin D in the human C-cell line Journal of Biological Chemistry 264 15743-15746

Kiriyama T, Gillespie MT, Glatz JA, Ho P, Fukomoto S, Moseley JM and Martin TJ (1991) Regulation of parathyroid hormone-related protein (PTHrP) gene expression by transforming growth factor beta-1 Journal of Bone and Mineral Research 6 (Supplement 1) A572

Lu C, Ikeda K, Deftos LJ, Gazdar AF, Mangin M and Broadus AE (1989) Glucocorticoid regulation of parathyroid hormone-related peptide gene transcription in a human neuroendocrine cell line Molecular Endocrinology 3 2034-2040
Martin TJ (1988) Humoral hypercalcaemia of malignancy Bone Mineral 4 83-89

Martin TJ, Moseley JM and Gillespie MT (1991) Parathyroid hormone-related protein: biochemistry and molecular biology Critical Reviews in Biochemistry and Molecular Biology 26 377-395

Moniz C, Burton PB, Malik AN, Dixit M, Banga JP, Nicolaides K, Quirke P, Knight DE and McGregor AM (1990) Parathyroid hormone-related peptide in normal human fetal development Journal of Molecular Endocrinology 5 259-266

Moseley JM, Kubota M, Diefenbach-Jagger H, Wettenhall REH, Kemp BE, Suva LJ, Rodda CP, Ebeling PR, Hudson PJ, Zajac JD and Martin TJ (1987) Parathyroid hormone-related protein purified from a human lung cancer cell line Proceedings National Academy of Sciences, USA 84 5048-5052

Moseley JM, Hayman JA, Danks JA, Alcorn D, Grill V, Southby J and Horton MA (1991) Immunohistochemical detection of parathyroid hormone-related protein in human fetal epithelia Journal of Clinical Endocrinology and Metabolism 73 478-484

Paspaliaris V, Vargas SJ, Gillespie MT, Williams ED, Danks JA, Moseley JM, Story ME, Pennefather JN, Leaver DD and Martin TJ (1992) Oestrogen enhancement of the myometrial response to exogenous parathyroid hormone-related protein (PTHrP) and tissue localisation of endogenous PTHrP and its mRNA in the virgin rat uterus Journal of Endocrinology 134 415-425

Rentrop M, Knapp B, Winter H and Schweitzer J (1986) Aminoalkylsilanetreated glass slides as support for in situ hybridisation of keratin cDNAs to frozen tissue sections under varying fixation and pretreatment conditions Histochemical Journal 18 271-276

Robertson EJ (1987) Embryo derived stem cells. In Teratocarcinomas and Embryonic Stem Cells: a Practical Approach, p 87 Ed. EJ Robertson. IRL Press, Oxford

Rodan SB, Wesolowski G, lanacone J, Thiede MA and Rodan GA (1989) Production of parathyroid hormone-like peptide in a human osteosarcoma cell line: stimulation by phorbol esters and epidermal growth factor Journal of Endocrinology 122 219-227

Sambrook J, Fritsch EF and Maniatis T (1989) Molecular Cloning: a Laboratory Manual (2nd Edn) Cold Spring Harbor Laboratory Press, New York

Selvanayagan P, Graves K, Cooper C and Rajaraman S (1991) Expression of the parathyroid hormone-related peptide gene in rat tissues Laboratory Investigation 64 713-717

Senior PV, Heath DA and Beck F (1991) Expression of parathyroid hormonerelated protein mRNA in the rat before birth: demonstration by hybridisation histochemistry Journal of Molecular Endocrinology 6 281-290

Suva LJ, Winslow GA, Wettenhall REH, Kemp BE, Hudson PJ, DiefenbachJagger H, Moseley JM, Rodda CP, Martin TJ and Wood WI (1987) A parathyroid hormone-related protein implicated in malignant hypercalcaemia: cloning and expression Science 237 893-896

Thiede MA (1989) The mRNA encoding a parathyroid hormone-like peptide is produced in mammary tissue in response to elevations in serum prolactin Molecular Endocrinology 3 1443-1447

Thiede MA and Rodan GA (1988) Expression of a calcium mobilising parathyroid hormone-like peptide in lactating mammary tissue Science 242 278-280

Thiede MA, Daifotis AG, Weir EC, Brines ML, Burtis WJ, Ikeda K, Dryer BE, Garfield RE and Broadus AE (1990) Intrauterine occupancy controls expression of the parathyroid hormone-related peptide gene in preterm rat myometrium Proceedings of the National Academy of Science, USA 87 6969-6973

Thiede MA, Harm SC, Hasson DM and Gardner RM (1991) In vivo regulation of parathyroid hormone-related peptide messenger ribonucleic acid in the uterus by $17 \beta$-oestradiol Endocrinology 128 2317-2323 